\title{
PORNOGRAFI PADA LIRIK LAGU-LAGU DANGDUT
}

\author{
Muchofatus Sholichah, Agung Pramujiono \\ Pendidikan Bahasa dan Sastra Indonesia, Fakultas Keguruan dan IlmuPendidikan, \\ Universitas PGRI Adi Buana Surabaya \\ muchofatussholichah22@gmail.com, agungpramujiono.unipasby@gmail.com
}

\begin{abstract}
ABSTRAK
Dangdut merupakan genre musik yang sudah tidak asing lagi bagi masyarakat Indonesia, musik dangdut sangat "Merakyat bagi bangsa Indonesia" sejak zaman berdirinya negara Indonesia. Karena lagu dangdut disukai oleh masyarakat Indonesia dari semua lapisan masyarakat, banyak pencipta lagu dangdut sekarang untuk dapat menarik simpati dan peminat pendengarnya membuat sebuah mahakarya dengan pilihan kata dalam lirik lagu yang dibuat tidak memiliki makna nilai moral, etika dan moral. kesopanan. Penelitian ini menggunakan pendekatan kualitatif dan metode deskriptif. Data yang dikumpulkan berupa sepuluh lagu dangdut lirik yang terdapat pada berita sepuluh lagu dangdut yang diblokir oleh pemerintah KPID NTB tahun 2012. Sumber data dalam penelitian ini adalah berita elektronik yang diambil dari internet sepuluh lagu dangdut yang diblokir oleh KPID pemerintah NTB tahun 2012. Pengumpulan data dilakukan dengan cara dokumentasi. Teknik analisis data sebagai berikut meneliti data yang telah ditemukan, mengklasifikasikan data yang telah ditemukan, mengkodekan data yang telah ditemukan, menafsirkan, atau menafsirkan data yang telah ditemukan, dan menyimpulkan hasil analisis. Berdasarkan analisis, hasil yang diperoleh dari penelitian "Pornografi pada Sepuluh Lirik Lagu Dangdut" mampu mengetahui pemilihan gaya kata yang digunakan oleh pengarang adalah jenis gaya kata konotatif, konkrit dan vulgar yang mengarah pada penggambaran bentuk dan sifat alat vital manusia dan biasa disebut dengan aktivitas seksual atau pornografi.
\end{abstract}

Kata kunci: Pornografi, Pemilihan Gaya Kata atau diksi, Lirik musik dangdut.

\section{PENDAHULUAN}

Bahasa adalah alat komunikasi verbal yang digunakan manusia untuk berhubungan antar sesamanya. Seseorang dapat terlibat dalam suatu komunikasi dalam suatu percakapan akrab maupun formal, seperti bercakap-cakap, diskusi, seminar, debat, dan lain sebagainya (menyimak dan berbicara) : demikian pula proses komunikasi dapat dikembangkan melalui media tulis, seperti menulis surat, mengarang, membaca buku, membaca majalah dan surat kabar (membaca dan menulis). Bahasa juga merupakan seperangkat lambang bunyi yang bersistem, sebagai hasil kerja artikulator manusia seperti lidah, gigi, rongga mulut, dan paruparu.(Basir,2014:2). Jadi bahasa sangat penting bagi kehidupan manusia untuk menyampaikan pendapat dan pikirannya. Lagu dangdut merupakan aliran musik yang sudah tidak asing bagi masyarakat Indonesia, dangdut adalah musik yang sangat " Merakyat bagi bangsa Indonesia " sejak zaman berdirinya negara Indonesia. Karena lagu dangdut banyak di sukai oleh kalangan masyarakat Indonesia dari segala golongan masyarakat, banyak pencipta lagu dangdut sekarang untuk dapat menarik simpatik dan peminat pendengar membuat sebuah karya dengan pemilihan kata pada lirik-lirik lagu yang dibuat maknanya tidak ada 
nilai moral, etika dan kesopanan. Seperti di zaman sekarang banyak lagu-lagu dangdut yang beredar di masyarakat Indonesia yang liriknya mengandung unsur pornografi hal-hal yang tabu atau tidak sepantasnya untuk diucapkan dan di perdengarkan pada pendengar atau penikmat lagu dangdut malah dibuat ajang mencari simpatik masyarakat agar mendapatkan popularitas dan materi yang berlimpah.

Berdasarkan alasan tersebut peneliti tertarik untuk meneliti lebih lanjut tentang bentuk pornonografi yang terdapat pada lirik lagu dengan objek artikel berita artikel sepuluh lirik lagu dangdut yang di cekal oleh KPID NTB karena dianggap mesum. Proses analisis ini menggunakan teori pemilihan gaya kata atau diksi, pengertian diksi adalah seleksi kata-kata untuk mengekspresikan ide atau gagasan dan perasaan. Diksi yang baik adalah pemilihan kata-kata secara efektif dan tepat di dalam makna, serta sesuai untuk pokok masalah, audien, dan kejadian (Ahmadi, 1990 : 136). Sedangkan menurut Al-Ma'ruf (2010:29) diksi diartikan sebagai pemilihan kata yang dilakukan oleh pengarang dalam karyanya. Dari pendapat tersebut ditemukan esensi bahwa diksi digunakan oleh pengarang dalam karyanya agar memperoleh efek tertentu.

Terdapat banyak jenis diksi berdasarkan maknanya dalam sebuah bahasa dan karya antara lain: 1) Kata konotatif adalah kata yang mengandung makna komunikatif yang terlepas dari makna harfiahnya yang didasarkan atas perasaan dan atau pikiran pengarang atau persepsi pengarang tentang sesuatu yang dibahasakan (Al-Ma'ruf, 2009:53). Jadi kata konotatif adalah kata yang bermakna kiasan atau tidak langsung. 2) Kata Konkret Al-Ma'ruf (2009:53) mengemukakan bahwa kata konkret adalah kata yang mengandung makna yang merujuk kepada pengertian langsung atau memiliki makna harfiah, sesuai dengan konvensi tertentu. Jadi dapat disimpulkan bahwa kata konkret bisa dikatakan sebagai kata yang memiliki maksud atau makna asli sesuai dengan konvensi tertentu yang digunakan untuk menggambarkan sesuatu dengan tepat dan jelas. Kata konkret bisa dikatakan sebagai kata nyata atau bermakna denotatif. Kata denotatif adalah kata yang bermakna sebenarnya. 3) Kata vulgar merupakan kata-kata yang carut dan kasar atau kampungan (Yusuf dalam Al-Ma'ruf, 2009:57). Kata vulgar merupakan kata-kata yang tidak intelek, kurang beradab, dipandang tidak etis, dan melanggar sopan santun atau etika sosial yang berlaku dalam masyarakat intlek atau terpelajar (AlMa'ruf, 2009:57). Kata vulgar merupakan kata-kata kasar, tidak senonoh, dan tidak beradab yang melanggar norma kesopanan secara umum yang bertujuan untuk menyampaikan berbagai ekspresi. 4) Kata serapan adalah kata yang diambil dari bahasa lain, baik bahasa asing maupun bahasa daerah, baik mengalami adapatasi struktur, tulisan, dan lafal, maupun tidak dan sudah dikategorikan sebagai kosakata bahasa Indonesia (Al-Ma'ruf, 2009:56). 5) Nama diri yang dipakai sebagai sapaan adalah kata yang dipakai untuk menyebut diri seseorang (Kridalaksana, dalam Al-Ma'ruf, 2009:54). AlMa'ruf (2009:54) menyatakan bahwa nama dapat diartikan sebagai kata yang berfungsi sebagai sebutan untuk menunjukkan orang atau sebagai penanda identitas seseorang. Nama diri merupakan sebutan atau penanda identitas seseorang yang juga dapat merupakan sebuah simbol atas suatu hal tertentu, sehingga penamaan tersebut memiliki rujukan tertentu yang dianggap sebagai simbol untuk memotivasi seseorang yang memiliki identitas tersebut. 6) Kata 
dengan objek ralitas alam merupakan kata yang memanfaatkan realitas alam sebagai bentukan kata tertentu yang memiliki arti (Al-Ma'ruf, 2009:57). Jadi yang dimaksud dengan kata dengan objek ralitas alam adalah kata-kata yang digunakan untuk merujuk pada objek-objek yang ada di alam.

Kamus besar bahasa Indonesia, merumuskan pornografi sebagai: 1) Penggambaran tingkah laku secara erotis dengan lukisan atau tulisan untuk membangkitkan nafsu birahi. 2)Bahan bacaan yang sengaja dan semata-mata di rancang untuk membangkitkan nafsu birahi / seks. Kalau kita perhatikan rumusan ini, maka letak kekuatan pornografi adalah pada kemampuannya yang besar untuk membangkitkan birahi mereka yang menatap dan menikmatinya. (Azimah, 2008:28) Beberapa contoh pornografi yang banyak beredar di masyarakat: (1) Lagu-lagu berlirik mesum atau lagu-lagu yang mengandung bunyi-bunyian atau suara-suara yang dapat diasosiasikan dengan kegiatan seksual. (2) Cerita pengalaman seksual di radio dan telepon (sex phone). (3) Jasa layanan pembicaraan tentang seks melalui telepon (party line). (4) Flim-flim yang mengandung adegan seks atau menampilkan artis dengan penampilan minim atau tidak (seolah-olah tidak) berpakaian. (5) Penampilan penyanyi atau penari latar dengan pakaian serba minim dan gerakan sensual dalam klip video-musik di TV dan VCD.(6) Gambar atau foto adegan seks atau artis yang tampil dengan gaya sensual. (7) Iklan-iklan di media cetak yang menampilkan artis dengan gaya yang menonjolkan daya tarik seksual biasanya ditemukan pada iklan parfum, mobil, handphone, dan sebagainya. (8) Fiksi dan komik yang menggambarkan adegan seks dengan cara sedemikian rupa sehingga membangkitkan hasrat sesual. Dengan kata lain pornografi adalah segenap materi di media yang berpotensi atau representasi perilaku seksual manusia yang membangkitkan hasrat seksual. Sementara pertunjukan yang bermuatan seksual meski tidak melalui media massa (live show) seperti tarian telanjang, organ tunggal, konser Madonna, goyang Inul dan sejenisnya, maka ada yang mengkategorikannya sebagai pornografi, namun ada juga yang yang mengkatagorikannya sebagai pornoaksi. (Azimah, 2008:33).

\section{METODE PENELITIAN}

Penelitian bahasa pemilihan kata pornografi pada lirik lagu-lagu dangdut ini menggunakan pendekatan deskriptif kualitatif. Penelitian mengenai bahasa berupa penelitian pornografi lirik sepuluh lagu dangdut yang dicekal pemerintah KPID NTB karena dianggap mesum menggunakan pendekatan deskriptif kualitatif. Data dalam penelitian kualitatif diwujudkan dalam kata kerja, sifat dan keadaan. Dalam hal ini peneliti lebih menggunakan pendapat dari Mukhtar yaitu data primer ini terdapat dalam kumpulan lirik sepuluh lagu dangdut yang dicekal pemerintah KPID NTB yang dianggap mesum yaitu lagu-lagu yang berjudul: (1) Jupe Paling Suka 69,(2) Mobil Bergoyang,(3) Apa Aja Boleh, (4) Hamil Duluan (5) Maaf Kamu Hamil Duluan,(6) Satu Jam Saja,(7) Mucikari Cinta,(8) Melanggar Hukum,(9) Wanita Lubang Buaya,(10) Ada yang Panjang. Data sekunder dalam analisis lirik lagu berupa buku-buku yang memuat teori mengenai bahasa, diksi atau pemilihan kata dan pornografi ditulis oleh berbagai ahli. Sumber data diperoleh dari berita elektronik atau artikel lirik sepuluh lagu dangdut yang dicekal oleh KPID NTB karena dianggap mesum pada 24 Februari 2012 oleh Cosa Aranda. Selain mengambil data dari berita eloktronik lewat interner juga mengambil buku-buka pendukung tentang bahasa, diksi dan 
pornografi. Teknik pengumpulan data digunakan dalam penelitian ini adalah teknik dokumen. Peneliti mengumpulkan lirik lagu-lagu dangdut yang berunsur pornografi. Informasi lirik lagu-lagu dangdut tersebut di dapatkan dari berita harian kompas yang berjudul 10 lagu yang di cekal oleh pemerintah karena mengandung unsur pornografi. Lirik lagu-lagu tersebut di kumpulkan. Untuk pengumpulan data ini hanya menggunakan media internet. Keabsahan data pada penelitian berikut ini menggunakan triangulasi sumber data dalam penelitian ini yaitu mencari objek yang akan diteliti oleh peneliti untuk dijadikan sumber data dalam penelitiannya. Sumber data dalam triangulasi sumber data ini kumpulan lirik sepuluh lagu dangdut yang di cekal pemerintah KPID NTB dianalisis dari pemilihan kata yang berunsur pornografi. Metode pengumpulan data dilakukan dengan mengidentifikasi dan mengklasifikasi data untuk memperoleh kebenaran mengenai objek kajian dengan rumusan masalah. Sedangkan yang terakhir triangulasi teori, peneliti melakukan pengkajian berbagai teori yang relevan, sehingga penelitian tidak menggunakan satu teori tapi ada diantaranya beberapa teori yang tidak jauh dengan teori yang digunakan.

\section{HASIL PENELITIAN}

Dalam lirik sepuluh lagu dangdut yang di cekal oleh pemerintah KPID NTB ini gaya kata yang digunakan oleh pencipta lagu kebanyakan memilih gaya kata atau diksi jenis, kata konotatif, kata kongkret, dan kata vulgar yang menjurus pada makna pornografi. jadi jika orang mendengar lagu tersebut langsung yang tertangkap di pikiran adalah sebuah ungkapan orang yang sedang bercinta dalam konteks bahasa yang bermakna tindakan hubungan seks. Berikut ini ditemukan gaya kata atau diksi pada lirik 10 lagu yang mengandung unsur pornografi:

1) Gaya kata konotatif berunsur pornografi

a) minta cium boleh, minta peluk boleh

apa aja boleh, semuanya boleh

minta ini boleh, minta itu boleh

apa aja boleh, semuanya boleh

b) ada yang panjang, ada yang pendek ada yang lentur, ada yang bengkok

pikiran lelaki mau nekat takut sendiri

cari rejeki kok malah dicaci maki

ada yang dalam, ada yang cetek

ada yang luwes, ada yang sempit

pikiran wanita takut susah ganti pasangan

nggak tahunya salah gaet suami orang

inilah lagu hanya lagu banyolan

c) wanita kamu harus tahu

mengapa lelaki buaya

mau tahu jawabannya

wanita punya lubang buaya

Dalam gaya kata ini peneliti menemukan kata (a). minta ini boleh, minta itu boleh apa aja boleh, semuanya boleh (b) ada yang panjang, ada yang pendek ada 
yang lentur, ada yang bengkok. ada yang dalam, ada yang cetek ada yang luwes (c) wanita punya lubang buaya yang termasuk konotatif karena pemilihan kata yang digunakan pada lirik lagu - lagu diatas membuat orang akan berfikiran yang lain atau memiliki rasa yang berbeda dalam menangkap kata tersebut. Dan kata pada lirik diatas yang diblok oleh peneliti, menurut peneliti pengarangnya dengan sengaja memilih kata yang membuat orang akan berfikir pada hal-hal yang mengarah pada pornografi contoh ada panjang, pendek, lentur dan bengkok maksud katanya adalah menjurus pada penggambaran bentuk dan sifat dari alat vital laki-laki sedangkan kata dalam, cetek, luwes dan sempit, wanita punya lubang buaya menjurus pada penggambaran bentuk dan sifat dari alat vital wanita jadi lirik diatas termasuk mengandung pornografi karena penciptanya sengaja menggunakan kata-kata yang jika orang mendengar akan berfikir atau ikut membayangkan gambaran yang membangkitkan nafsu birahinya.

2) Gaya kata Kongkret berunsur pornografi

d) rupanya kau sang mucikari, seorang yang tak punya hati... awalnya aku dinikahi, pura-pura ku dicintai...

setelah itu dipaksa ku jual diri

rupanya kau sang mucikari, seorang yang tak punya hati...

sering engkau paksa diriku untuk melayani temanmu

bila ku menolak siksaan yang ku terima...

e) apakah aku telah melanggar hukum

\section{bila mencintai suami orang lain}

adakah undang-undang yang melarangnya

katakanlah aku melanggar pasal berapa

tapi harus bagaimana aku terlanjur cinta

sehingga aku rela walau jadi madunya

andai nanti aku ketahuan istrinya

Dalam gaya kata ini peneliti menemukan kata (d). mucikari (e). mencintai suami orang lain, jadi madunya yang termasuk kata kongkret karena pemilihan kata yang digunakan pada lirik lagu-lagu diatas makna yang terkandung merujuk pengertian langsung atau memiliki makna harfiahnya Dan kata pada lirik diatas yang diblok oleh peneliti, menurut peneliti pengarangnya dengan sengaja menggunakan katakata atau istilah-istilah yang sering digunakan pada dunia pornografi contoh dengan memunculkan kata mucikari orang sudah tau dan berfikir bahwa lirik lagu tersebut maknanya menceritakan tentang sebuah tempat atau wadah kelompok atau personal sengaja menjual diri untuk kepuasan seksualitas orang lain dan kata kata mencintai orang lain, jadi madunya dengan kata tersebut makna yang tersirat adalah efek dari tindak kecanduan pornografi yang berupa perselingkuhan, sehingga lirik diatas termasuk mengandung pornografi karena penciptanya sengaja menggunakan kata-kata yang jika orang mendengar akan berfikir atau ikut membayangkan gambaran yang membangkitkan nafsu birahinya.

3) Gaya kata Vulgar berunsur pornografi

f) suka suka jupe paling suka

kasih sayangmu luar biasa

gairah cinta 69 
g) yang penting senang bergoyang bergoyang

di setiap mobil digoyang digoyang

dipeluk cium merangsang merangsang

biarkan orang ah tegang ah tegang

h) $\boldsymbol{k u}$ hamil duluan sudah tiga bulan

gara-gara pacaran tidurnya berduaan

ku hamil duluan sudah tiga bulan

gara-gara pacaran suka gelap-gelapan

i) bila semua sudah terlanjur

terlanjur terjadi ya terlanjur

kau hamil duluan padahal pacaran

aku jadi sedih campur senang

j) 1 jam saja bercumbu denganmu

1 jam saja ku dimanjakanmu

1 jam saja ku bercumbu rayu

1 jam saja bercinta denganmu

Dalam gaya kata ini peneliti menemukan kata (f). gairah cinta 69 (g) dipeluk cium merangsang (h) hamil duluan (i) kau hamil duluan (j) bercumbu denganmu yang termasuk kata vulgar karena pemilihan kata yang digunakan pada lirik lagulagu diatas bersifat carut tidak senonoh atau tidak sopan dan kata pada lirik diatas yang diblok oleh peneliti, menurut peneliti pengarangnya dengan sengaja memilih kata yang membuat orang akan berfikir pada hal-hal yang mengarah pada pornografi contoh gairah cinta 69 adalah jika di dunia pornografi adalah cara bentuk gaya bercinta, dipeluk cium merangsang, hamil duluan dan bercumbu denganmu adalah kata yang medeskripsikan orang melakukan kenikmatan hubungan seksual. Jadi lirik diatas termasuk mengandung pornografi karena penciptanya sengaja menggunakan kata-kata yang jika orang mendengar akan berfikir atau ikut membayangkan gambaran yang membangkitkan nafsu birahinya.

\section{PEMBAHASAN}

Berdasarkan analisis data yang peneliti peroleh dalam kaitannya pornografi pada lirik sepuluh lagu Dalam penelitian ini pemilihan gaya kata atau diksi bermakna pornografi yang ditemukan adalah:(1) Diksi atau gaya kata konotatif kata yang di gunakan terlepas dari makna harfiahnya dan menunjukkan pada penggambaran bentuk struktur dan sifat alat vital manusia.(2) Diksi atau gaya kata kongkret ditemukan kata yang menggambarkan sesuatu dengan jelas bentuk efek penyimpangan dari pornografi memiliki berbagai cara dengan kerugiannya. Seperti selingkuh atau mucikari. (3) Diksi atau gaya kata Vulgar ditemukan banyak kata yang carut, tidak senonoh atau tidak sopan untuk dikatakan dengan penggambaran pergaulan bebas yaitu perilaku hubungan seksual atau aktivitas seks.

Pornografi memang sering dipersepsikan dengan cara yang beragam. Interpretasi pornografi diberi batasan yang berbeda-beda. Orang bebas mengartikan pornografi dengan cara yang tidak sama. Ada pihak yang memandang pornografi sebagai seks (berupa tampilan gambar,aksi maupun teks), 
namun ada juga pihak yang memandang pornografi sebagai seni/art (berupa cara berbusana, gerakan, mimik, gaya, cara bicara, atau teks yang menyertai suatu tampilan).

Kamus besar bahasa Indonesia, merumuskan pornografi sebagai :(1) Penggambaran tingkah laku secara erotis dengan lukisan atau tulisan untuk membangkitkan nafsu birahi. (2)Bahan bacaan yang sengaja dan semata-mata di rancang untuk membangkitkan nafsu birahi / seks. Kalau kita perhatikan rumusan ini, maka letak kekuatan pornografi adalah pada kemampuannya yang besar untuk membangkitkan birahi mereka yang menatap dan menikmatinya. (Azimah, 2008:28).

Secara etimologi, kata diksi berasal dari dictionary yang berarti perihal pemilihan kata. Pilihan kata ini terkait dengan kebenaran, kejelasan, keefektifan dalam pemakaian. Diksi (diction) adalah seleksi kata-kata untuk mengekspresikan ide atau gagasan dan perasaan. Diksi yang baik adalah pemilihan kata-kata secara efektif dan tepat di dalam makna, serta sesuai untuk pokok masalah, audien, dan kejadian (Ahmadi, 1990 : 136).

Sedangkan diksi menurut Al-Ma'ruf (2010:29) diksi diartikan sebagai pemilihan kata yang dilakukan oleh pengarang dalam karyanya. Dari pendapat tersebut ditemukan esensi bahwa diksi digunakan oleh pengarang dalam karyanya agar memperoleh efek tertentu. Menurut Al-Ma'ruf (2009:53) terdapat banyak diksi dalam karya sastra antara lain kata konotatif, konkret, kata vulgar, serapan, nama diri dan kata objek realitas alam.

Penafsiran dalam penelitian ini berusaha mendiskripsikan dan memaparkan tentang hasil dari proses analisis data. Analisis data dalam penelitian kali ini adalah pornografi yang terdapat pada lirik lagu dangdut yang dikaji melalui pemahaman pemilihan kata yang dipakai oleh pencipta lagu. Dengan demikian dari data yang penulis peroleh yang terdapat pada sepuluh lagu dangdut yang dikaji lebih banyak menggunakan gaya kata konotatif, kongkret dan vulgar, dari ketiga diksi tersebut peneliti menemukan fenomena bahwa pengarang pengarang lagu lebih condong memakai gaya kata vulgar pada karyanya karena kata tersebut lebih mengarah pada istilah-istilah dunia pornografi. Misalnya kata hamil duluan kata tersebut adalah kata yang kasar bila dijadikan penggunaan dalam berkomunikasi karena maknanya yang mengandung dari efek akibat pergaulan bebas atau seks bebas, nakal, dan lain sebagainya. Hasil penelitian ini menemukan bahwa bentuk pornografi bisa terjadi melalui media lirik lagu dangdut bahkan pornografi dijelaskan secara lebih terperinci dan esensi kenikmatan rasa yang unik karena pendukung nada-nada dalam lagu tersebut dengan menggunakan pemilihan gaya kata yang tepat dan sesuai dengan keinginan pencipta sehingga makna dapat tersampaikan dengan gamblang atau jelas ke penikmat atau pendengar lagu tersebut.

\section{SIMPULAN}

Berdasarkan hasil penelitian maka dapat disimpulkan bahwa pada sepuluh lirik lagu dangdut yang telah diteliti pencipta lagu lebih banyak menggunakan pemilihan kata jenis gaya kata atau diksi konotatif (khiasan), kongkret (makna yang sebenarnya) dan vulgar (carut atau kasar) yang maknanya mengarah pada penggambaran bentuk dan sifat alat vital manusia dan perilaku hubungan seksual atau aktivitas seks jadi ketika posisi pendengar atau penikmat lagu mendengarkan 
lirik lagu tersebut dilantunkan atau dinyanyikan pola pikirnya akan membayangkan hal-hal yang dipaparkan pada lirik tersebut sehingga dapat memacu untuk memunculkan hasrat nafsu birahinya, fenomena yang seperti itu bisa dimasukkan dalam kategori tindak pornografi. Jadi penyebaran bentuk pornografi bisa terjadi berbagai cara salah satunya adalah melalui sebuah media seni musik dangdut yang disukai oleh berbagai kalangan masyarakat Indonesia.

\section{SARAN}

Dari penelitian ini semoga dapat menambah pengetahuan terhadap perkembangan keilmuan, teknologi sesuai dengan bidang ilmu yang sedang dibahas khususnya dalam penelitian tentang pornografi dalam bentuk bahasa. Penelitian ini diharapkan dapat dijadikan sebagai acuan untuk peneliti selanjutnya.

\section{DAFTAR PUSTAKA}

Al-Ma'ruf, Ali Imron. 2009. Stilistika Teori, Metode, dan Aplikasi Pengkajian Estetika Bahasa. Solo: Cakra books

Ahmadi, Mukhsin. 1990. Dasar-Dasar Komposisi Bahasa Indonesia. Malang:Yayasan Asih Adah Asuh Malang.

Basir, Pr. M. Basir. 2014. Keterampilan Menulis Dasar Menulis Ilmiah dalam Tulisan Latin dan Jawa (Pengantar Teori dan Praktik). Surabaya: Penerbit Bintang Surabaya

www.liriklaguindonesia.net, 2012, "Ini Dia 10 Lagu Dangdut yang Dianggap Porno",https://liriklaguindonesia.net/ini-dia-10-lagu-dangdut-yangdianggap porno.htm. Diunduh pada tanggal 01 Desember 2015 pukul 21.00

Mukhtar. 2013. Metode Praktis Penelitian Deskriptif Kualitatif. Jakarta: Referensi (GP Press Group)

Soebagijo, Azimah. 2008. Pornografi Dilarang tapi Dicari. Jakarta: Gema Insani.. 